\title{
ANALISIS PENGAKUAN PENDAPATAN DAN BEBAN PADA PT.PEGADAIAN (PERSERO) CABANG MEGAMAS
}

\author{
Oleh \\ Ricky Michael Datulangie \\ Agus Toni Poputra \\ Program Pendidikan Profesi Akuntansi \\ Fakultas Ekonomi dan Bisnis \\ Universitas Sam Ratulangi Manado \\ Email: ricky.datulangie@yahoo.com
}

\begin{abstract}
Companies are required to arrange their financial statements because it is the important basis to determine the recognition of revenues and expenses in accordance with the applicable rules. The research object in this case is PT. Pegadaian (Persero) Megamas Branch. The purpose was to determine and evaluate the implementation of the recognition of revenues and expenses in PT. Pegadaian (Persero) Megamas Branch. Data analysis is using qualitative method. The type of data is using primary data. Source of the data is using documentation method. This study found that the company adopted PSAK No. 23 (Revised 2010), Revenues, which identifies the fulfillment of the criteria of revenue recognition, the recognition of revenues and expenses done by using the accrual basis, and measurement of revenue recorded by the cash receipts in accordance with PSAK No. 23, paragraph 8.
\end{abstract}

\section{Keywords: Revenue and Expense Recognition, Financial Statement.}

\section{PENDAHULUAN}

\section{Latar belakang}

Pada saat ini, individu maupun organisasi memiliki tujuan yang mendasar. Secara umum yang dimaksudkan dengan tujuan adalah segala sesuatu yang dicari/diinginkan, serta yang dibutuhkan untuk dicapai. Individu atau organisasi, pada dasarnya bertujuan mendapatkan laba semaksimal mungkin agar kelangsungan usaha dapat berlanjut dari masa ke masa.

Pegadaian merupakan BUMN (Badan Usaha Milik Negara) yang mayoritas kepemilikannya adalah pemerintah dengan laba bersih setahun hampir dua triliun, harus mempertanggung jawabkan laporan keuangan yang telah diumumkan untuk menciptakan kepercayaan pengguna informasi termasuk pemerintah sendiri. Dalam laporan laba rugi, jumlah pendapatan dan beban menjadi tolak ukur apakah perusahaan bisa bertahan pada masa yang akan datang. Berdasarkan latar belakang tersebut, penulis memilih judul: analisis pengakuan pendapatan dan beban pada PT.Pegadaian (Persero) Cabang Megamas. 


\section{TINJAUAN PUSTAKA Pengertian pendapatan}

Pendapatan adalah arus kas masuk aktiva dan atau penyelesaian kewajiban akibat penyerahan atau produksi barang, pemberian jasa, atau kegiatan menghasilkan laba lainnya yang membentuk operasi utama atau inti perusahaan yang berkelanjutan selama satu periode.

FASB (Financial Accounting Standard Board) dikutip oleh Harahap (2003:240), mendefinisikan pendapatan sebagai arus masuk atau peningkatan nilai aset dari suatu entitas atau penyelesaian kewajiban dari entitas atau gabungan keduanya selama periode tertentu yang berasal dari penyerahan produksi barang, pemberian jasa atas pelaksanaan kegiatan lainnya yang merupakan kegiatan utama perusahaan.

Menurut Keenan (2014), pedapatan adalah bagian terpenting dalam mempersiapkan laporan keuangan, evaluasi entitas dan profibilitasnya. Pendapatan merupakan indikator untuk pembentukan laba, oleh karena itu pendapatan diukur secara wajar sesuai prinsip pengakuan pendapatan untuk diterapkan guna mengukur pendapatan yang diterima sebenarnya oleh perusahaan (Sitepu, 2014).

\section{Pengakuan pendapatan}

Salah satu permasalahan utama dari elemen pendapatan adalah proses pengakuan pendapatan (revenue recognition). Pengakuan (recognition) mengacu pada saat atau waktu dimana suatu transaksi tersebut, baik dalam kata-kata maupun jumlahnya, dimana jumlahnya mencakup angka-angka ringkas yang dilaporkan dalam laporan keuangan.

Menurut kriteria pengakuan pendapatan jasa yang terdapat dalam PSAK No. 23 Ikatan Akuntan Indonesia (2010), suatu entitas dapat mengakui pendapatan jika memenuhi kriteria sebagai berikut.

a. Jumlah pendapatan dapat diukur dengan andal

b. Besar kemungkinan manfaat ekonomi sehubungan dengan transaksi tersebut akan diperoleh perusahaan.

c. Tingkat penyelesaian dari suatu transaksi pada tanggal neraca dapat diukur dengan modal.

d. Biaya yang terjadi untuk transaksi dan untuk menyelesaikan transaksi

\section{Pengertian beban}

tersebut dapat diukur dengan andal.

Beban adalah jumlah keluaran dari harga perolehan terhadap barang atau jasa yang diserahkan, modal saham yang dikeluarkan atau liabilitas yang dibebankan sebagai imbalan dari barang atau jasa yang diterima perusahaan untuk memperoleh pendapatan dalam satu periode akuntansi akan terus melekat dan membentuk harga perolehan aset (Rismansyah, 2015).

Menurut Standar Akuntansi Keuangan (Ikatan Akuntan Indonesia [IAI], 2007:13), beban adalah penurunan manfaat ekonomi selama satu periode akuntansi dalam bentuk arus keluar atau berkurangnya aset atau terjadinya kewajiban yang mengakibatkan penurunan ekuitas yang tidak menyangkut pembagian kepada penanaman modal.

\section{Pengakuan beban}

Menurut Ikatan Akuntan Indonesia [IAI] (2012), pengakuan beban dinyatakan sebagai berikut.

1. Beban diakui dalam laporan laba rugi komprehensif jika penurunan manfaat ekonomi masa depan yang berkaitan dengan penurunan aset atau peningkatan liabilitas telah terjadi dan dapat diukur dengan andal. 
2. Beban diakui dalam laporan laba rugi atas dasar hubungan langsung antara biaya yang timbul dan pos penghasilan tertentu yang diperoleh (matching expense of costs with revenues).

3. Beban diakui dalam laporan laba rugi komprehensif atas dasar prosedur alokasi yang rasional dan sistematis dalam periode akuntansi yang menikmati manfaat. Hal ini sering diperlukan dalam pengakuan beban yang berkaitan dengan penggunaan aset seperti aset tetap, goodwill, paten, merek dagang. Dalam kasus semacam itu, beban ini disebut penyusutan atau amortisasi.

4. Beban segera diakui dalam laporan laba rugi komprehensif kalau pengeluaran tidak menghasilkan manfaat ekonomi masa depan atau jika manfaat ekonomi masa depan tidak memenuhi syarat, atau tidak lagi memenuhi syarat, untuk diakui dalam neraca sebagai aset.

5. Beban juga diakui dalam laporan laba rugi komprehensif pada saat timbul kewajiban tanpa adanya pengakuan aset, seperti apabila timbul liabilitas tanpa adanya pengakuan aset, seperti apabila timbul liabilitas akibat garansi produk.

\section{METODE PENELITIAN Jenis data}

Penelitian ini menggunakan jenis data sekunder yang menyediakan informasi ataupun data perusahaan.

\section{Metode pengumpulan data}

Dalam penelitian ini mengunakan metode dokumentasi untuk memperoleh sumbersumber dokumen yang berkaitan dengan penelitian atau data-data yang sudah didokumentasikan oleh pihak perusahaan berupa profil perusahaan, struktur organisasi perusahaan, dan laporan keuangan perusahaan.

\section{Metode analisis}

Metode analisis yang digunakan dalam penelitian ini adalah analisis kualitatif dengan memperhatikan prosedur pengakuan pendapatan dan beban, kemudian mendokumentasi informasi prosedur pengakuan pendapatan dan beban tersebut dengan menggunakan skema informasi dan kemudian menganalisa dan dibuat kesimpulan.

\section{HASIL PENELITIAN DAN PEMBAHASAN Hasil penelitian \\ Pendapatan}

PT.Pegadaian (Persero) Cabang Megamas mempunyai banyak produk untuk menjawab kebutuhan masyarakat. Mulai dari pengguna produk konsumtif, produktif, investasi, pembayaran angsuran listrik, pengiriman uang dan tabungan emas.

Pegadaian Cabang Megamas memperoleh pendapatan dari sewa modal dan administrasi dari produk KCA (Kredit Cepat Aman), KREASI (Kredit Angsuran Sistem Fidusia), KRASIDA (Kredit Angsuran Sistem Gadai), Jasa Taksiran dan Titipan, MPO (Multi Payment Online), dan MULIA. Keuntungan dari hasil lelang, diberikan kembali pada nasabah. Hal ini tidak diakui sebagai pendapatan.

\section{Beban}

Beban pada PT.Pegadaian (Persero) secara keseluruhan yang dipelajari meliputi beban pegawai, beban umum, dan beban administrasi pemasaran. Beban pegawai dalam hal ini gaji dibayarkan pada tanggal 25 dan tunjangan tidak tetap dibayarkan pada tanggal 26 tiap bulan. 
Insentif pencapaian omset dibayar setiap tiga bulan sekali. Pembayaran jasa produksi dibayarkan dua tahap yaitu tahap pertama sebagai uang muka pada bulan april dan sisanya dibayarkan antara bulan agustus.

Beban sewa di amortisasi setiap akhir bulan memakai accrual basis method dalam laporan laba rugi perusahaan sebelum memulai tahun pelaporan keuangan yang baru, management telah menyusun anggaran pada periode berikut. Anggaran yang dibuat berdasarkan data pencapaian beban pada periode sebelumnya.

Beban ditangguhkan dalam perusahaan adalah beban yang telah dikeluarkan dan mempunyai manfaat lebih dari satu tahun. Beban yang dimaksud adalah sebagai berikut.

1. Beban rehabilitasi gedung sewa, diamortisasi sesuai dengan masa manfaatnya.

2. Beban pengurusan legal hak atas tanah, diamortisasi sepanjang umur hak atas tanah tersebut. Merupakan hak guna bangunan yang mempunyai masa manfaat selama 20 tahun.

3. Biaya RUF (Revolving Underwriter Facility) adalah seluruh biaya yang berkaitan dengan fasilitas pinjaman sindikasi.

\section{Pembahasan}

Pendapatan sewa modal pada produk KCA dan KREASI menerapkan metode akrual (Accrual Basis) yang dibuktikan pada saat terjadinya transaksi penyaluran kredit, hal ini dibuktikan karena perusahaan bisa mengukur jumlah sewa modal dengan andal yang merupakan pendapatan dan dipastikan diterima pada masa yang akan datang atau saat jatuh tempo kredit. Hal ini telah sesuai dengan PSAK No 23 (revisi 2010) jika hasil transaksi yang terkait dengan penjualan jasa dapat diestimasi dengan andal.

Pendapatan administrasi PT. Pegadaian (Persero) Cabang Megamas diakui pada saat terjadinya transaksi penyaluran kredit karna perusahaan telah mengestimasi jumlah dan waktu yang andal yang akan diterima pada masa yang akan datang.

Beban diakui pada saat terjadinya transaksi berdasarkan metode akrual. Perusahaan telah mengetahui pasti waktu pembayaran beban dilakukan. Akun biaya sewa gedung di akui pada saat transaksi dan akun beban sewa gedung dibayar dimuka diamortisasi pada laporan akhir bulan sesuai manfaat yang diterima perusahaan.

\section{KESIMPULAN}

Berdasarkan hasil penelitian dan pembahasan ini, maka penulis membuat kesimpulan sebagai berikut.

1. Perusahaan dan entitas anak menerapkan PSAK No. 23 (Revisi 2010), "Pendapatan", yang mengidentifikasi terpenuhinya kriteria pengakuan pendapatan, sehingga pendapatan dapat diakui, dan mengatur perlakuan akuntansi atas pendapatan yang timbul dari transaksi dan kejadian tertentu, serta memberikan panduan praktis dalam penerapan kriteria mengenai pengakuan pendapatan.

2. Pengakuan pendapatan dan beban pada PT. Pegadaian (Persero) dilakukan dengan menggunakan akrual basis karena pengaruh transaksi dan peristiwa lain diakui pada saat kejadian bukan pada saat kas diterima atau dibayar. Hal tersebut telah sesuai dengan acuan PSAK No. 23 paragraf 19 tentang pendapatan penjualan jasa.

3. Pengukuran pendapatan dicatat sebesar penerimaan kas yang diterima dan sebesar nilai wajar dari yang diberikan untuk memperoleh pendapatan tersebut. Hal ini telah sesuai 
dengan PSAK No. 23 paragraf 8. Pelaporan pendapatan dan beban telah dilakukan berdasarkan akun masing-masing pendapatan dan beban sesuai dengan klasifikasinya. Saran-saran yang dapat diberikan oleh peneliti adalah sebagai berikut.

1. Penerapan pengakuan pendapatan dan beban pada PT.Pegadaian (Persero) telah sesuai dengan ketentuan yang berlaku dan diharapkan perusahaan dapat melanjutkan ketentuan tersebut dimasa yang akan datang untuk kepentingan shareholder.

2. Dalam penyajian laporan keuangan, akun pembayaran sewa gedung dibayar dimuka tidak diberikan penjelasan tentang jangka waktu amortisasi. Informasi tambahan ini seharusnya diberitahukan pada bagian disclosure.

3. Pendapatan administrasi yang diterima dimuka harusnya diamortisasi sesuai dengan jangka waktu kredit. Akun ini harus dilaporkan sebagai akun piutang dalam aktiva lancar.

\section{DAFTAR PUSTAKA}

Harahap, S. S. (2003), Teori Akuntansi, Penerbit PT Raja Grafindo Persada, Jakarta. Ikatan Akuntan Indonesia (IAI) 2007, Standar Akuntansi Keuangan (SAK). Jakarta:

Salemba Empat

Ikatan Akuntan Indonesia (IAI) 2010, Standar Akuntansi Keuangan (SAK). Jakarta:

Salemba Empat

Ikatan Akuntan Indonesia (IAI) 2012, Standar Akuntansi Keuangan (SAK). Jakarta:

Salemba Empat

Keenan, J. (2014), "The Impact of The Revenue Recognition Project", Thesis (tidak dipublikasikan),

Department of Accounting and the Robert D. Clark Honors College. Diakses dari https://scholarsbank.uoregon.edu/xmlui/bitstream/handle/1794/18257/T hesis\%20Final Jack.pdf? sequence $=1$

Rismansyah dan Safitri, N. (2015), "Analisis Pengakuan Pendapatan Dan Beban

Pada PT. Wahana Bumi Riau Cabang Palembang”, Jurnal Media

Wahana Ekonomika, 12 (2), 51-74.

Sitepu, W. S. (2014), "Analisis Pengakuan Pendapatan dan Beban (Studi kasus pada kantor Notaris / PPAT Denilah Shofa Nasution, S.H, M.Kn)", Jurnal Ilmiah Accounting Changes, 2 (1), 16-25. 